\title{
PROGRAM KEMITRAAN MASYARAKAT (PKM) \\ PEMBERDAYAAN KELOMPOK PEREMPUAN MELALUI PEMBINAAAN KEWIRAUSAHAAN DI KELURAHAN TARA-TARA TOMOHON
}

\author{
Henny Lenni Suot \\ Universitas Negeri Manado \\ lenny.suot04@gmail.com
}

\begin{abstract}
Abstrak
Program Kemitraan Masyarakat ini bertujuan untuk; 1). Meningkatkan keterampilan dan minat Kelompok Perempuan di Kelurahan Tara-tara Tomohon dalam berwirausaha, 2). Meningkatkan pemahaman Kelompok Perempuan di Kelurahan Tara-tara Tomohon mengenai Berwirausaha dan Kewirausahaan, 3). Peningkatan Pemberdayaan Kelompok Perempuan dalam hal berwirausaha di Kelurahan Tara-Tara Tomohon. Program Kemitraan Masyarakat ini dilaksanakan di Kelurahan Tara-Tara Tomohon menggunakan metode ceramah, diskusi dan evaluasi. Simpulan yang didapatkan dari Program Kemitraan Masyarakat ini adalah bahwa Pelaksanaan dan Evaluasi Pemberdayaan Kelompok Perempuan di Kelurahan Tara-Tara Tomohon diikuti dengan antusias oleh kelompok perempuan, para kelompok perempuan di Kelurahan Tara-Tara Tomohon menunjukan antusiasnya dengan dating tepat waktu dan mengikuti seluruh kegiatan pemberdayaan yang diberikan oleh tim pelaksana. Evaluasi dalam program ini dilakukan secara sederhana dengan mencatat setiap kegiatan dengan hasilnya dan adanya monitoring dari pemerintah selaku pihak penyelenggara pelatihan dan pendampingan, untuk mengetahui sejauh mana perkembangan produk yang nantinya akan dihasilkan
\end{abstract}

]Kata kunci: Pemberdayaan, Kelurahan Tara-Tara, Kelompok Perempuan

\section{PENDAHULUAN}

\section{Analisis Situasi}

Perempuan merupakan komponen yang ada di masyarakat yang bisa dilibatkan dalam pembangunan. Potensi kaum perempuan dalam kehidupan masyarakat masih belum mendapat porsi yang wajar. Hal seperti ini perlu disikapi secara arif dan bijaksana oleh pemerintah mengingat kaum perempuan dari kuantitas menempati urutan pertama dari komposisi warga masyarakat. Perempuan sebagai warga negara yang memiliki hak dan kewajiban yang sama dengan laki-laki,

Perempuan lebih banyak tertinggal dalam mengakses layanan publik, pendidikan, kesehatan, dan aspek lain, sehingga menjadi kaum yang rentan dan miskin. Kemiskinan pada perempuan bukan hanya dari segi materi, namun juga akibat pengaruh budaya yang belum menempatkan perempuan untuk mendapatkan kesempatan yang sama dalam sejumlah aspek kehidupan. Akses perempuan pada sumber daya, terutama beberapa pekerjaan formal di bidang ekonomi, menjadi terbatas karena faktor budaya yang mengesampingkan peran perempuan [1]. Beberapa anak perempuan usia sekolah sering tidak mendapatkan pendidikan karena tidak diizinkan untuk mengikuti kegiatan belajar-mengajar oleh keluarga atau norma sosial di daerahnya. Bahkan, mereka juga tidak diperbolehkan untuk mengikuti pendidikan berbasis keterampilan yang mungkin bisa 
bermanfaat guna mendukung perekonomian keluarganya. Keputusan untuk memperoleh pendidikan, untuk bekerja, dan melakukan kegiatan ekonomi lainnya dipengaruhi oleh keluarga dan terkait dengan budaya yang berlaku di kelompok masyarakat tertentu. Di beberapa wilayah di Indonesia, anak perempuan sejak dini diharapkan untuk melakukan pekerjaan rumah tangga. Kontrol sosial dan keluarga makin membatasi kapasitas perempuan untuk membuat keputusan mandiri [2]. Peluang perempuan untuk keluar dari kemiskinan terhambat oleh sedikitnya keterampilan yang dimiliki, sehingga jenis pekerjaan yang dapat dilakukan mereka terbatas pada kegiatan informal yang tidak membutuhkan keterampilan khusus.

Pemberdayaan adalah merupakan salah satu wadah yang dijadikan sebagai upaya untuk memberikan wahana bagi masyarakat dalam memenuhi akan kebutuhan warga belajar berupa pengetahuan dan keterampilan yang berkaitan bagi kehidupan yang lebih baik di dalam kehidupan keluarga dan masyarakat. Konsep pemberdayaan merupakan suatu upaya untuk menjadikan sesuatu yang adil dan beradab menjadi lebih efektif dalam seluruh aspek kehidupan. Pemberdayaan perempuan melalui pelatihan berwirausaha merupakan suatu pembelajaran dalam upaya meningkatkan pengetahuan, dan keterampilan perempuan. Kegiatan pelatihan kewirausahaan diharapkan berdampak pada kemampuan/keberdayaan perempuan menciptakan lapangan kerja. Melalui pelatihan kewirausahaan dalam memanfaatkan potensi alam yang berada di lingkungan setempat, perempuan dapat meningkatkan kesejahteraan hidupnya

Keterlibatan perempuan dalam kegiatan pemberdayaan berkaitan erat dengan kemampuan untuk meningkatkan kondisi ekonomi keluarga. Kegiatan yang inovatif memungkinkan mereka mempelajari berbagai macam keterampilan untuk memperoleh penghasilan dan memperluas jaringan, karena telah terhubung dengan kesempatan dan inovasi. Beberapa usaha sosial bergerak untuk membantu perempuan memperoleh penghasilan dan meningkatkan status sosial mereka dalam masyarakat. Kewirausahaan sosial memberikan solusi untuk berbagai permasalahan social [3]. Secara eksplisit, kewirausahaan sosial menggabungkan perspektif bisnis dan sosial dalam upaya menciptakan kemandirian ekonomi melalui kegiatan pemberdayaan. Penggabungan perspektif bisnis dan sosial ini menimbulkan pertanyaan bagaimana praktik kewirausahaan sosial dapat berpengaruh terhadap perubahan sosial dalam masyarakat. Studi ini menjawab pertanyaan mengenai hubungan antara keikutsertaan dalam program kewirausahaan sosial terhadap kegiatan pemberdayaan perempuan dan perubahan sosial yang ditimbulkannya. 
Keberhasilan penyelenggaraan program pelatihan kewirausahaan ini sangat ditentukan oleh kesadaran kelompok perempuan yang memerlukan peningkatan kemampuan berusaha dan keterampilan dirinya dalam memanfaatkan sumber potensi alam agar dapat mengolah dan memasarkan berbagai macam jenis hal-hal di bidang tata boga sehingga diharapkan peserta mampu mengaplikasikan hasil belajarnya yang ditandai dengan adanya perubahan taraf hidup yang mencakup memperoleh pekerjaan/ menciptakan lapangan kerja atau berwirausaha, peningkatan pendapatan, ekonomi, percaya diri dan mengikutsertakan orang lain dalam pemanfaatan hasil belajarnya dan berperan serta dalam kegiatan sosial dan pembangunan masyarakat. Dalam kegiatan pelatihan usaha masih terdapat berbagai permasalahan sehingga tidak semua peserta pelatihan dapat melakukan kegiatan usaha dan juga maasih ada usaha peserta yang sedang berkembang atau kurang berkembang.

Usaha yang dapat dikatakan sebagai jawaban permasalahan di atas adalah dengan mendirikan berbagai lembaga pelatihan begitu juga keterampilan kerja. Atmodiwirio mendefinisikan pelatihan sebagai pembelajaran yang dipersiapkan agar pelaksanaan pekerjaan sekarang meningkat [4]. Dalam hal ini, peranan pemerintah daerah dalam meningkatkan perekonomian dan ketenagakerjaan wanita yaitu mengembangkan ketenagakerjaan secara mandiri dan terpadu yang diarahkan terutama pemberdayaan perempuan untuk peningkatan kompetensi serta kemandirian tenaga kerja, peningkatan upah pekerja, menjamin kesejahteraan, perlindungan kerja dan kebebasan berserikat, serta melakukan berbagai upaya terpadu untuk mempercepat proses pengentasan masyarakat dari kemiskinan juga mengurangi pengangguran yang merupakan dampak krisis ekonomi.

Sesuai dengan Undang-undang Republik Indonesia Nomor 20 Tahun 2003 tentang Sistem Pendidikan Nasional Bab VI bagian kelima pasal 26 ayat 2 dan 5 bahwa : "..(2) Pendidikan non-formal berfungsi mengembangkan potensi peserta didik dengan penekanan pada penguasaan pengetahuan juga keterampilan fungsional serta pengembangan sikap dan kepribadian profesional. (5) Kursus juga pelatihan diselenggarakan bagi masyarakat yang memerlukan bekal pengetahuan, keterampilan, kecakapan hidup dan sikap untuk mengembangkan diri, mengembangkan profesi, bekerja, usaha mandiri dan atau melanjutkan pendidikan ke jenjang yang lebih tinggi." [5].

Berdasarkan permasalahan di atas maka peranan pemerintah daerah dalam meningkatkan pemberdayaan perempuan dilakukan berdasarkan program pembangunan nasional (PROPENAS) tahun 2000-2004 dalam Undang-undang Nomor 
25 Tahun 2000 Bab VIII butir 3 adalah: (1) meningkatkan kedudukan dan peran perempuan dalam kehidupan berbangsa dan bernegara melalui kebijakan nasional yang diemban oleh lembaga yang mampu memperjuangkan terwujudnya kesetaraan dan keadilan gender, (2) meningkatkan kualitas peran dan kemandirian organisasi perempuan dengan tetap mempertahankan nilai persatuan dan kesatuan, meningkatkan nilai histories perjuangan kaum perempuan dalam rangka melanjutkan usaha pemberdayaan perempuan serta kesejahteraan keluarga [6].

Pelatihan kewirausahaan adalah suatu langkah penting dan perlu dilakukan dalam rangka membentuk/ mencetak sumber daya manusia yang berkualitas. Tujuan akhir yang ingin dicapai yaitu program pelatihan ini yang nantinya akan berdampak dalam meningkatkan keterampilan bidang usaha dan mempunyai sikap jiwa kewirausahaan dan diharapkan akan mampu menciptakan kemandirian baik dalam sikap maupun dalam berusaha. Program pelatihan kewirausahaan bertujuan agar perempuan mempunyai peningkatan dalam hal pengetahuan, keterampilan, dan sikap, sehingga dapat mengaplikasikan hasil belajarnya dalam pengelolaan usaha nanti yang ditandai dengan melakukan wirausaha melalui pemanfaatan potensi sumber daya alam yang ada di lingkungan.

\section{Permasalahan Mitra}

Dari anaslisi situasi di atas maka ditemukan permasalah mitra yaitu
1. Masih ditemukan kurangnya pemberdayaan kelompok perempuan dalam hal berwirausaha di Kelurahan Tara-Tara Tomohon.

2. Kurangnya keterampilan dan minat dari kelompok perempuan di Kelurahan Tara-Tara Tomohon dalam berwirausaha.

3. Kurangnya pemahaman Kelompok Perempuan di Kelurahan Tara-tara Tomohon dalam berwirausaha dan Kewirausahaan

\section{SOLUSI DAN TARGET LUARAN}

\section{Luaran dan Target Capaian}

Rencana Luaran

1. Kelompok Perempuan di Kelurahan Tara-tara Tomohon memiliki keterampilan dan minat dalam berwirausaha.

2. Meningkatnya pemahaman Kelompok Perempuan di Kelurahan Taratara Tomohon mengenai Berwirausaha dan Kewirausahaan

3. Peningkatan Pemberdayaan Kelompok Perempuan dalam hal berwirausaha di Kelurahan Tara-Tara Tomohon.

Solusi yang di tawarkan

Solusi yang ditawarkan untuk mengatasi permasalahan yang dihadapi di Kelurahan Tara-Tara Tomohon adalah: 
1. Pemaparan Konsep mengenai Kewirausahaan dan berwirausaha

2. Pemaparan Konsep Pengelolaan Kewirausahaan

3. Pemaparan Kelebihan dan keuntungan yang didapat dalam berwirausaha

4. Pemaparan keterampilan dan kreatifitas dalam berwirausaha

\section{METODE PELAKSANAAN}

Pelaksanaan kegiatan PKM di Kelurahan Tara-tara Tomohon. Kegiatan ini ditujukan untuk membantu menyelesaikan permasalahan yang dihadapi oleh Mitra, kegiatan dilakukan dengan menggunakan metode ceramahm yang nantinya diikuti oleh diskusi dengan mitra yang menjadi peserta lalu diadakan evaluasi dari hasil kegiatan program kemitraan masyarakat

1. Pendekatan kepada mitra dengan memberikan pemahaman tentang rencana program PKM

2. Membantu memberikan pelatihan kewirausahaan.

3. Memberikan pemaparan materi mengenai:
a. Konsep
kewirausahaan danberwirausaha
b. Konsep peneglolaan kewirausahaan
c. Kelebihan dan keuntukngan

dalam berwirausaha

d. Keterampilan dan kreatifitas dalam berwirausaha

4. Pemberian penyuluhan dan pendampingan materi materi yang telah diberikan sebelumnya

5. Dilakukan diskusi kelompok antar para mitra dan tim pelaksana mengenai pemaparan materi yang telah diberikan sebeumnya oleh tim pelaksana

\section{Evaluasi}

\section{HASIL DAN PEMBAHASAN}

Partisipasi Kelompok Perempuan dalam meningkatkan taraf ekonomi menjadi kekuatan utama dalam mewujudkan kehidupan yang sejahtera. Melalui Program pelatihan Kewirausahaan kepada Kelompok Perempuan di Kelurahan Tara-Tara Tomohon yang diharapkan dapat menjadi wadah dalam mewujudkan kesejahteraan tersebut bersama masyarakat. Dalam melaksanakan setiap program, perencanaan senantiasa dilakukan sebagai bagian dari suatu program yang akan diselenggarakan. Perencanaan ini menyangkut bagaimana suatu program harus dan akan dilaksanakan. Wawasan anggota sudah lebih luas mengenai bagaimana cara menemukan ide untuk berwirausaha dengan bijak dan benar , pengetahuan yang dimiliki pun tentunya bertambah lebih banyak, keterampilan dan sikap yang telah dimiliki anggota 
diantaranya adalah sikap ingin maju dan mandiri dengan memiliki keahlian membuat usaha dengan terampil. para anggota Kelompok Perempuan di Kelurahan TaraTara Tomohon mengikuti program Pendidikan Kewirausahaan Masyarakat (PKM) ini telah dengan baik, dari berbagai keahlian yang telah diberikan ilmu dan teorinya kepada mereka.

Pemberdayaan Kelompok Perempuan Melalui Binaan Kewirausahaan

Menurut Oda, proses pemberdayaan perempuan mencakup kegiatan [7]:

a) menemukan masalah, hambatan dan peluang untuk mengembangkan perikehidupan mereka melalui Partisipatori Reseach Apraisal (PRA). Merencanakan kegiatan hasil identifikasi dengan menggunakan teknik perencanaan partisipatif,

b) mengakses sumber daya yang tersedia (baik internal maupun eksternal) yang bisa mendukung kegiatan masyarakat,

c) melaksanakan kegiatan sesuai dengan perencanaan yang sudah ditetapkan sebelumnya,

d) membangun dan melaksanakan sistem monitoring dan evaluasi untuk membantu perempuan dalam menilai perkembangan, melakukan perubahan kegiatan yang diperlukan dan menetapkan kegiatan selanjutnya."

Dampak yang dialami peserta didik atau lulusan setelah memperoleh dukungan dari masukan lain. Dampak tersebut yaitu menambah penghasilan keluarga, ibu-ibu dapat bekerja tanpa harus meninggalkan rumah, lebih mandiri, mampu mengembangkan produk yang berkualitas. dapat diketahui bahwa penyelenggaraan program tersebut berdampak positif bagi semua lapisan masyarakat mulai dari anggota kelompok sampai masyarakat

Evaluasi dalam program ini dilakukan secara sederhana dengan mencatat setiap kegiatan dengan hasilnya dan adanya monitoring dari pemerintah selaku pihak penyelenggara pelatihan dan pendampingan, untuk mengetahui sejauh mana perkembangan produk yang nantinya akan dihasilkan.

Dampak positif dari adanya penyelenggaraan program pemberdayaan kelompok perempuan di Kelurahan TaraTara Tomohon adalah:

a) menambah penghasilan keluarga,

b) ibu-ibu mempunyai kegiatan diwaktu luang selain mengurus rumah tangga,

c) perempuan menjadi lebih mandiri, dan

d) bertambahnya pengetahuan mengenai cara mengembangkan produk yang dihasilkan.

\section{KESIMPULAN}


Pelaksanaan dan Evaluasi Pemberdayaan Kelompok Perempuan di Kelurahan TaraTara Tomohon diikuti dengan antusias oleh kelompok perempuan, para kelompok perempuan di Kelurahan Tara-Tara Tomohon menunjukan antusiasnya dengan dating tepat waktu dan mengikuti seluruh kegiatan pemberdayaan yang diberikan oleh tim pelaksana. Evaluasi dalam program ini dilakukan secara sederhana dengan mencatat setiap kegiatan dengan hasilnya dan adanya monitoring dari pemerintah selaku pihak penyelenggara pelatihan dan pendampingan, untuk mengetahui sejauh mana perkembangan produk yang nantinya akan dihasilkan.

\section{REFERENSI}

[1] Brahme, S. (1984). Producers' cooperatives: Experience and lessons from India (Occasional Paper No. 99). The Hague, Netherlands: Institute of Social Studies.

[2] Gregorio. (1966) School Administration and Supervision. Quezon. Gracia

[3] Nicholls, A. (2006). Social Entrepreneurship: New Models of Sustainable Social Change. New York: Oxpord University Press.

[4] Atmodiwirio. (2002). Manajemen Pelatihan. Jakarta: PT Pustaka

[5] Undang-undang Republik Indonesia Nomor 20 Tahun 2003 tentang Sistem Pendidikan Nasional

[6] Program Pembangunan Nasional (PROPENAS) tahun 2000-2004 dalam Undang-undang Nomor 25 Tahun 2000
[7] Oda. (2011). Peningkatan Pendapatan Keluarga di Daerah Wisata Melalui Pemberdayaan Perempuan. Diakses dari e-journal. Kopertis4.or.id/file/Peningkatan\%20Penda patan $\% 20$ KeluargaPdf 